\title{
Energy-Related Occupant Behaviour and Its Implications in Energy Use: A Chronological Review
}

\author{
Vivian W. Y. Tam * (D), Laura Almeida and Khoa Le \\ School of Computing, Engineering and Mathematics, Western Sydney University, Penrith, NSW 2751, Australia; \\ 1.almeida@westernsydney.edu.au (L.A.); lenkhoa@gmail.com (K.L.) \\ * Correspondence: vivianwytam@gmail.com
}

Received: 15 May 2018; Accepted: 23 July 2018; Published: 26 July 2018

\begin{abstract}
It is essential to understand how significantly occupants' actions impact the performance of a building, as a whole, in terms of energy use. Consequently, this paper reviews the available resources on energy-related occupant behaviour and its implications in energy use in a building. A chronological review on energy-related occupant behaviour and its implications in energy use has been conducted. As a main existing gap, it was identified by researchers the difference between real energy performance and the one that is predicted during the design stage of a building. The energy predicted during the design stage of a building may be over twice the energy used in the operation stage. Buildings are one of the most energy intensive features in a country. They are affected by the interaction and correlation of several different variables, such as: its physical characteristics, technical systems, equipment, occupants, etc. Therefore, buildings are considered to be complex systems that require a careful and intensive analysis. Moreover, one of the key variables impacting real building energy use is occupant behaviour. The way occupants behave and their motivations are some of the main aspects that need to be considered in a building life-cycle.
\end{abstract}

Keywords: occupant behaviour; energy-related behaviour; energy efficiency; energy use; driving forces; green building

\section{Introduction}

According to the International Energy Agency (IEA), the building sector is responsible for $40 \%$ of the primary energy use in the majority of the IEA member countries [1]. In Australia, buildings represent $58 \%$ and $34 \%$ of all electrical and natural gas final uses, respectively [2]. Even though the energy intensity has been improving, achieving a 1.8\% decrease in 2015 due to energy efficiency measures and policies that were implemented by national governments, in order to drive the world towards decarbonised energy systems, countries need to reach a $2.6 \%$ reduction in the intensity of energy per annum [3].

One of the major contributions to high rates of energy intensity is the way that occupants deal with energy. The impact that occupants have in the energy performance of a building is extremely significant. Past studies showed that the difference between predicted energy and real energy use is mainly due to the way that occupants behave in terms of energy use [4,5]. This behaviour has several direct and indirect factors that may have influence in the way that occupants consume energy. These factors may be due to objective aspects such as climate, air velocity, temperature, noise, accessibility to control building features, time, and activity type, as well as to other subjective factors, such as the perception of comfort, expectations, gender, age [6,7], values, and social interaction. These factors may also be influenced by external features, such as politics, economics, and culture. Figure 1 intends to represent all of the correlations mentioned previously. 


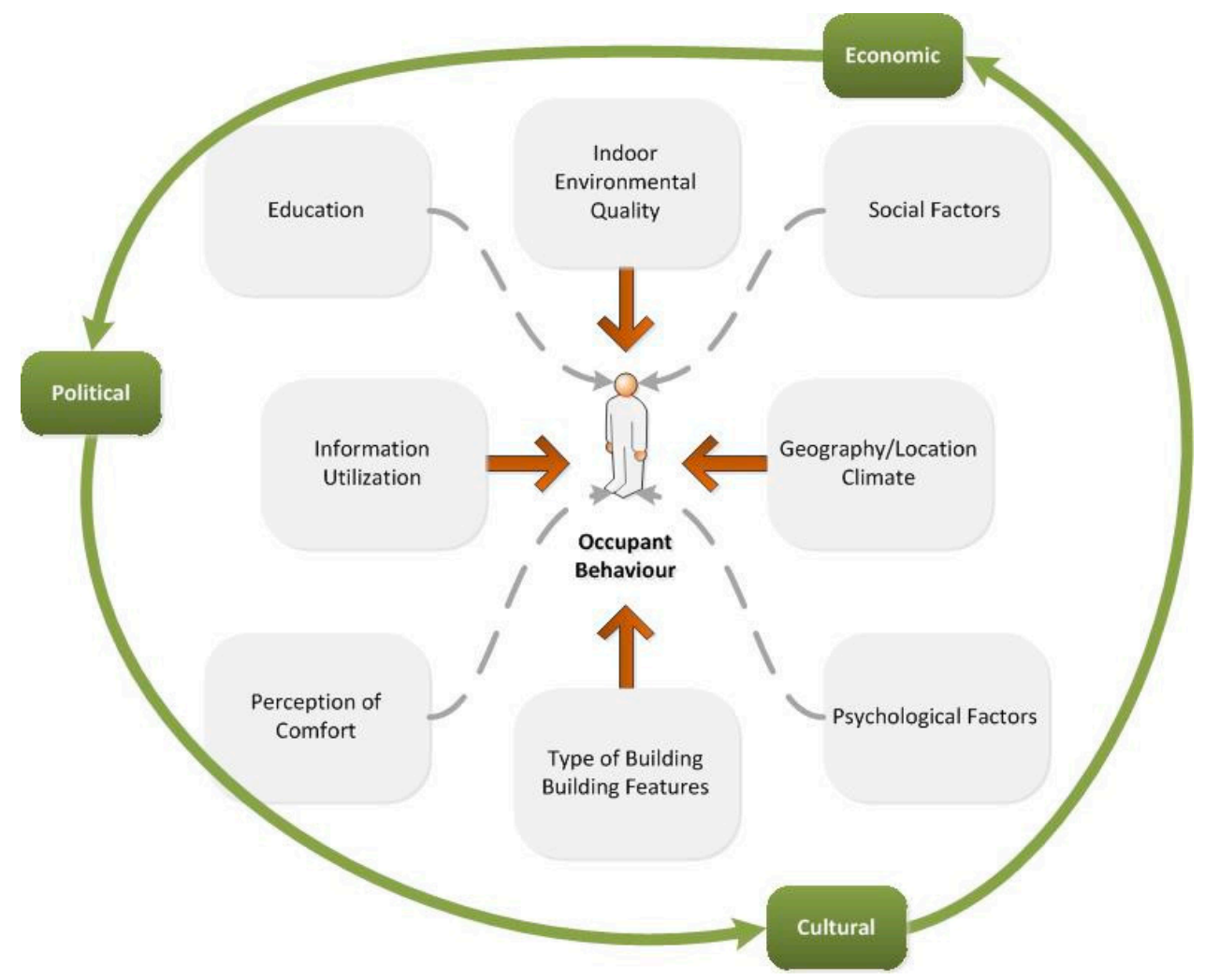

Figure 1. Influential factors on occupant behaviour.

This paper reviews energy-related occupant behaviour, its direct or indirect impact in the way occupants use and perceive energy, and consequently, their implications in energy use. The purpose of this paper is to provide a chronological overall review the main key points in energy-related occupant behaviour research, the main conclusions, and the most relevant gaps.

\section{Methodology}

In order to develop this research a chronological methodology was established, according to Figure 2. The first step was to go as further as to the first energy-related occupant behaviour research, available in literature. Then, it was identified the field of research and pointed out the main conclusions. The first studies, in the early 50's and 60's were focused in the interactions that occupants had towards opening windows and ventilation systems [8]. Furthermore, as it is possible to see in Figure 7, it was analyzed the evolution of the research fields throughout the decades, either related with new fields of research or with additional innovative contributions to existing ones.

Only after the mid 80's, the number of fields of studies that were related with how occupants behave in terms of energy use started to grow exponentially. These studies were mainly directed to stochastic models [9], a perspective of thermal comfort [10] and adaptive occupant behavior [11]. Moreover, after 2010 the number of new fields of research in literature started to slow down and researchers were concentrated in developing new approaches to existing fields of research, having as an example the understanding of the gap between predicted and real energy use [12].

Finally, in 2017, Hong et al. in order to answer and understand occupant behavior in terms of energy use, formulated ten questions having as baseline issues, such as: monitoring techniques for human-building interaction, behavior modeling approaches, promoting social science insights, analyzing achieved results, and enriching building performance simulation programs. With this, the author aimed to guide future researchers, designers, and policy makers and promote innovation in the area of energy efficiency [13]. 


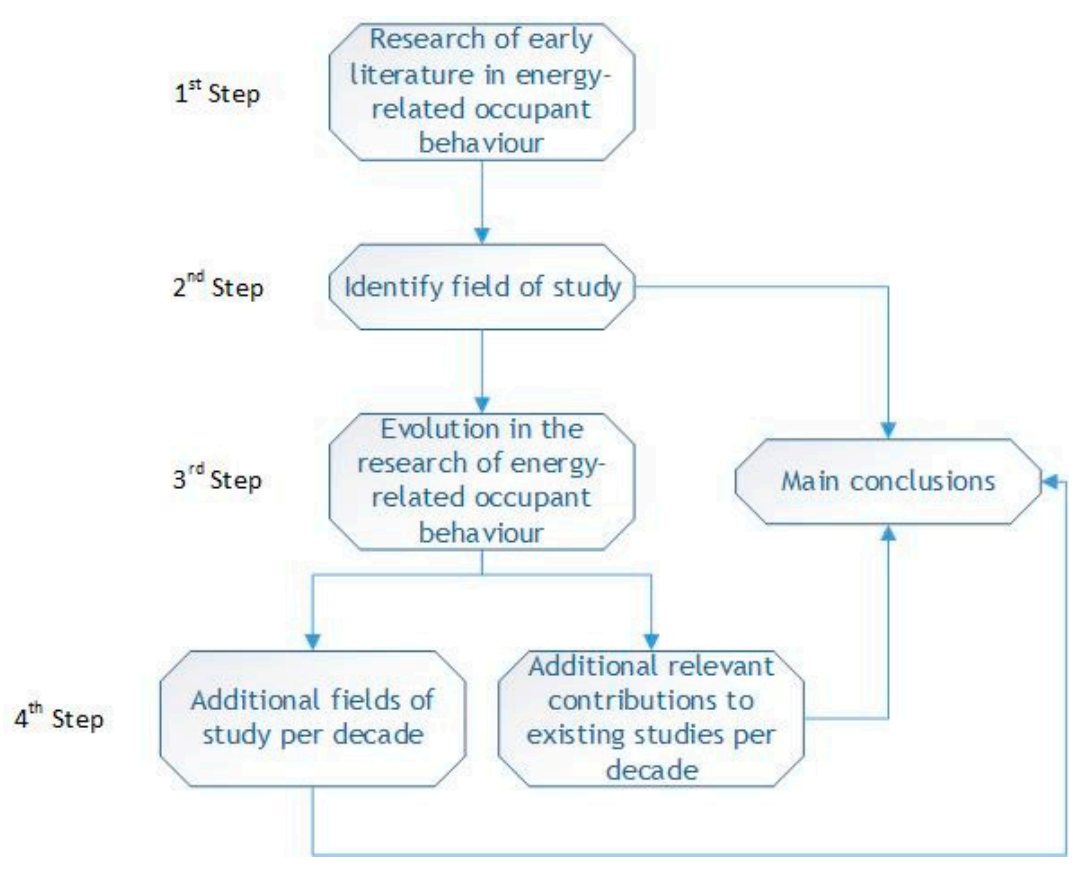

Figure 2. Methodology used in this research.

\section{Early Stages of Energy-Related Occupant Behaviour Research}

Understanding how occupants behave has been a matter of interest of multiple different subjects in the past. Due to the obvious influence that occupants have in real building energy use, the interaction between occupants and energy use began to be a matter of interest since the early 50's. Earlier studies started discussing occupant interactions with window-opening and its implications in heat loss through air-change rates [8], as well as with the use of energy, by creating the first energy-related behavioural study in which a strong seasonal pattern in the occupant's opening windows habits was identified [14]. Furthermore, understanding the reasons that drive occupant to switch on and off lights and how they interact with artificial lighting [15], made it possible to find a direct relationship with minimum real and perceived illuminance, as well as with daylight levels. Moreover, ignoring occupant interaction with solar shading by analysing window blind use, would lead to an overestimation of energy savings [16].

\section{Occupant Behaviour and Thermal Comfort}

\subsection{Energy-Related Occupant Behaviour Models}

In the beginning of the 90 's, a series of projects and studies in the residential sector relating occupants' energy use to pattern analysis was conducted, and as a result match correctly occupant behaviour in $40-70 \%$ of the time $[17,18]$. With these studies, researchers were able to conclude that energy use varies from one household to another, appearing irrational or unexpected from an energy conservation perspective but full of sense in the context of family schedules, occupancy patterns, and comfort preferences. Therefore, in order to support conclusions that are related with the interactions of occupant and window opening researchers started using stochastic model based in the Markov chains, comparing real to generated data [9]; and later on, the first behavioural computer model FENESTRA was developed. This model, instead of using occupants as merely fixed heat generators, predicted occupant mobility and their relationship concerning thermal comfort, concluding that if traditional thermal models do not account with occupant mobility, it is expected to be an overestimation of the energy consumption [19]. Additionally, using the calibration of a DOE-2 model it was identified why the actual energy use in an office building is over twice as the predicted during the design stage. Mainly, one of the major factors impacting energy use was the unexpected 
occupant behaviour, which alone represented $64 \%$ of the difference between real and predicted energy. Heating, ventilation, and air-conditioning (HVAC) operation over the expected schedule represented $24 \%$ of the discrepancies; and, equipment inefficiencies, conductive heat losses, and divergences in the minimum outdoor-air rates were related to the remain $12 \%[4]$.

\subsection{Thermal Comfort and Control Systems}

The American Society of Heating, Refrigeration, and Air-Conditioning Engineers (ASHRAE) funded a series of field studies [20], for collecting both physical and subjective thermal comfort data in office buildings. This fact triggered that after the mid $90^{\prime}$ s the main concern of researchers was focused on thermal comfort and its implications in energy use. Similarly, occupants' wellbeing was a matter of study, and questions, such as indoor air quality (IAQ) and how occupants perceived comfort in a building, gained additional relevance. Therefore, in order to develop procedures for assessment and guidance to assure a good IAQ, while maintaining an optimized energy use, a European project was created that comprised the IAQ audits of 56 buildings in several European countries, having as inputs occupant's perception in relation with their thermal comfort, IAQ, and light and noise levels by means of a survey [21].

\subsubsection{Aspects Affecting Occupant Perception of Comfort}

Several aspects, such as occupant's life-style, demography, economy, interaction with building features and systems, as well as with equipment will affect occupant's perception of comfort and consequently the use of energy [10]. The cultural and economic contrast patterns among cities and countries needs to be taken into account, due to the fact that different profiles will be related to space heating, lighting, and hot water uses [22]. Consequently, there is a need of exploring more in detail adaptive behaviour, where the full comprehension of the "cognitive tolerance" concept allows for understanding on how to increase the extension of occupants' adaptive comfort zone and tolerance [11].

\subsubsection{Occupant Interaction with the Systems in a Building}

Researchers concluded that occupant satisfaction increased when they had the opportunity of controlling their interactions with the systems in bindings [23]. The problem was in the fact that this would not imply a reduction in the energy use of a building; and, a sequence of experiments using intelligent lighting occupancy sensors were conducted, determining that these sensors save $5 \%$ more energy than the ordinary ones, which by themselves could save up to $30 \%$ of electricity for lighting [24]. Moreover, the activation of Venetian blinds, besides reduce solar gain and glare, leads to an increase of the electric uses that are associated with lighting [25].

Another relevant fact is that $87 \%$ of the total air change rates were caused by occupant behaviour [26], which allowed researchers to try to understand this fact in several countries (United Kingdom, Pakistan and other European countries), concluding that there was no significant difference among countries relating outdoor temperature at which occupants started opening the windows for ventilation as well as that fans started to be used at around $15{ }^{\circ} \mathrm{C}$ and moved up to $100 \%$ when the outdoor temperature was around $30{ }^{\circ} \mathrm{C}$. Moreover, $50 \%$ of the heating uses began at $10{ }^{\circ} \mathrm{C}$ and increased up to $100 \%$ at $5{ }^{\circ} \mathrm{C}$. Furthermore, blinds were activated in $40-45 \%$ of the time and in European offices were practically independent of the outdoor temperature. In terms of lighting there was a direct correlation among hot dry countries, the turning on the lights and high outdoor temperatures [27].

\section{Behavioural Algorithms and Model Tools}

\subsection{Developed Algorithms}

The need of more reliable models that could mimic occupant behaviour started to emerge, and, in 2002, an adaptive control algorithm (ACA) was developed. To develop this algorithm, a series of 
field studies in five European countries (United Kingdom, France, Portugal, Greece, and Sweden) were conducted, where indoor environment quality (IEQ) parameters (such as air temperature, air velocity, $\mathrm{CO}_{2}$ concentration, illuminance at working plane) were measured and a survey that was based on the seven-point ASHRAE scale to assess subjective thermal comfort sensations and predict the mean vote (PMV) was carried out. Researchers were able to conclude that the ACA has potential to save up to $30 \%$ of the cooling load without compromising the perceived thermal comfort [28]. Another algorithm developed was the genetic algorithm (GA), which allowed for the study an automatic shading-device controller that learned the preferences of occupants regarding blind position and took into account the complex and unpredictable occupant behaviour on a long-term basis [29].

\subsection{Energy-Related Models and Tools}

Using the simulation program ENERWIN in order to evaluate the reasons for its high electrical use in 30 residences in Kuwait, allowed for researchers to reach the conclusion that annual energy use in residential buildings was directly related to occupant's location and life-style, and that data relating with the type of occupant should be as accurate as possible. Besides, just by reducing $2{ }^{\circ} \mathrm{C}$ in the air-conditioning thermostat and matching light schedules to occupancy patterns led to a decrease of $39 \%$ in electricity uses. Another aspect focused by the authors was related to the fact that occupants tend to left lights on even when there was no occupancy in the rooms and a rectification in this behaviour would led to a $29 \%$ decrease in energy use [30].

Another researcher developed a half-hourly data model to evaluate the lighting demand of 100 homes in the United Kingdom, in order to match the supply and demand for renewable energy technologies, and found that there was no simple linear relationship between demand and time of day in daily lighting profile due to the interaction of the availability of daylight and high variation in the behaviour of occupants [31]. Therefore, in order to predict the performance of the use of manually and automatically controlled electric lighting and blinds to mimic occupant behaviour the Lightswitch-2002 algorithm, while using the tool Lightswitch Wizard and the software DAYSIM, was developed, concluding that by using this tool it is possible to reach an average of $20 \%$ energy savings [32]. Meanwhile, by comparing the thermal energy uses in heating from a predicted model to a real performance based on a three-year monitoring period, it is possible to observe an increase of over $50 \%$ in thermal energy use. This was due to the fact that the real utilization settings were not considered, neither the real performance of technical systems nor the real climate conditions, in the theoretical values of the predicted model [5].

\subsection{Sustainability Tools}

After the mid 2000's, sustainability tools start to emerge or to have more relevance and the first studies linking occupant behaviour or satisfaction in the context of a Green Building. The relationship between task lighting on occupant's mood, satisfaction, and performance and its correlation to energy savings, using as reference illuminance values, as suggested by Green Star (Green Building Council of Australia-GBCA) and Illuminating Engineering Society of North America (IESNA) allowed for concluding that there was no direct association among these variables [33]. On the contrary, when comparing the actual energy intensity use to the baseline model of seven offices or libraries buildings, and four multi-family residential buildings certified by the green building certification tool LEED (Leadership in Energy and Environmental Design), it was possible to conclude that almost all of the buildings had savings of over $40 \%$, when compared to the design model projections, but there was no clear relationship between occupant satisfaction in comfort temperature and the building energy intensity [34].

\subsection{Factors Affecting Energy-Related Occupancy Behaviour}

The Markov model was used to analyse air conditioning on/off state systems and to determine effective schedules for air conditioning operation from inhabitant occupancy schedules. 
What influences occupant behaviour in turning on and off the air conditioner is reflected by social background, such as energy cost and moral sense, and if inhabitants made decisions that were not based on social background but their own thermal sensations, the probability functions are universal and ethnic differences in thermal sensation needed additional studies [35]. When analysing the percentage time, occupants will open a window if it is possible to affirm that seasonability, outdoor temperature and occupancy patterns have significant relevance in their behaviour [36]. The use of sensors, such as air volume and demand-controlled ventilation either by a $\mathrm{CO}_{2}$ sensor and an infrared occupancy sensor, to reduce energy consumption showed that it was possible to reduce energy uses by up to $38 \%$ and $51 \%$ associated with ventilation [37].

\subsection{Sub-Hourly Occupancy Control}

In order to study the influence of occupant behaviour in building energy simulation, it used the simulation software ESP-r coupled with the sub-hourly occupancy control (SHOCC) simulation module, with the aim of account with all phenomena related to occupancy and allowing the possibility of accessing empirically-derived behavioural models in a dynamic mode [38]. With the intension of obtaining a more realistic estimation of lighting uses, the behavioural model SHOCC was connected to the simulation tools DAYSIM and Lightswitch [39]. Figure 3 is based in the SHOCC modularity representing the encapsulation of data approach in the model. Using the author's example: IT equipment, lighting, and population; the encapsulation approach started with packets of information that had a small number of related data, such as power features to lighting and equipment or psycho-social qualities to individuals. Then, the packets were merged together to form a computer or an individual, and finally were grouped into clusters to enable the sharing of data and mutual functionality, such as schedule and control.

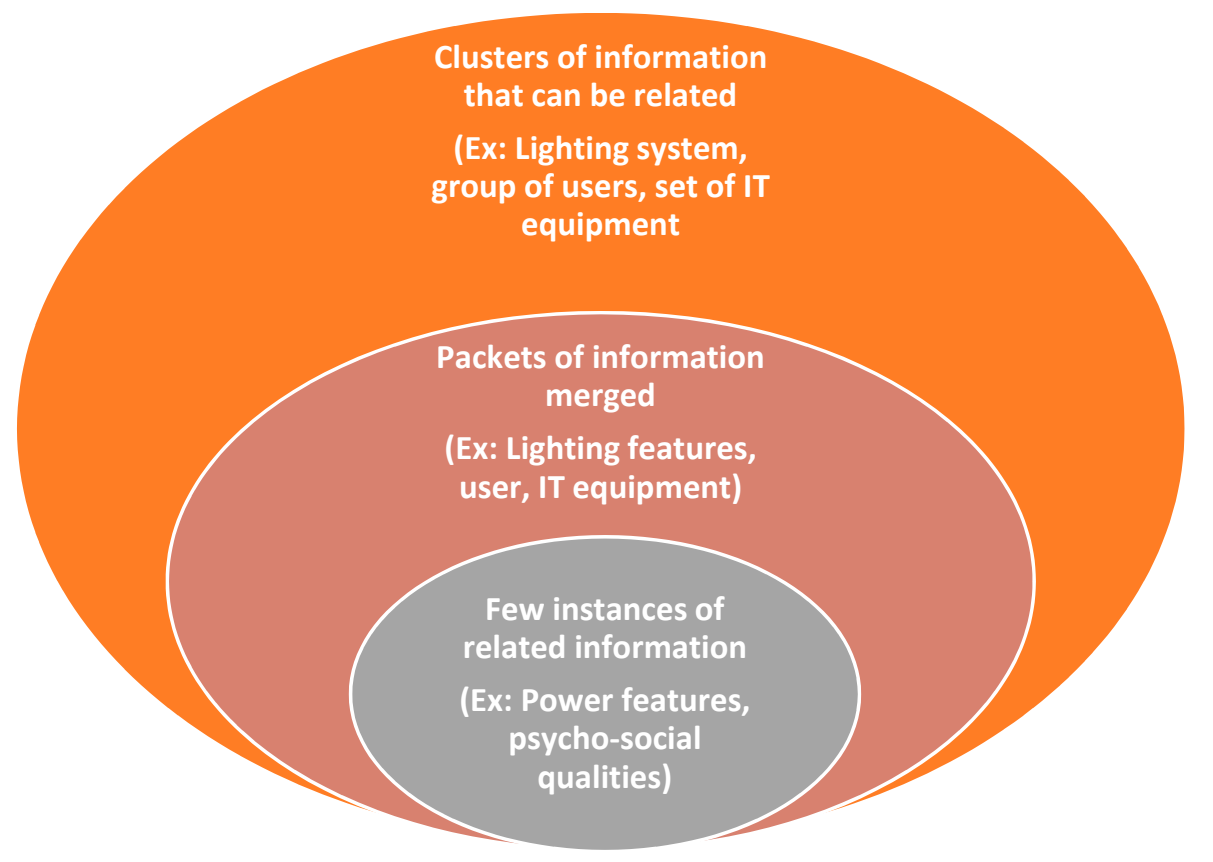

Figure 3. Sub-hourly occupancy control (SHOCC) data encapsulation [38].

\subsection{Predicted vs. Real Energy Uses}

After several energy measurements during a 15 years' period, in the residential sector in the Pacific Northwest of the United States, to understand how energy is used in space heating it was concluded that it is strongly affected by occupant behaviour, which is ignored in most energy simulations [40]. Therefore, in order to analyse the difference between measured and predicted energy performance of 
low-energy building located in Sweden, three different software tools were used. The first was based in a Microsoft Windows simulation tool, the second one was a transient simulation program and the third one corresponded to a simulation tool for modeling building performance, such as Transient System Simulation Tool (TRNSYS). All of the programs had a maximum variation between them of around $2 \%$ and reached a variance of $50 \%$ due to the higher indoor air temperatures that were imposed by occupants in their homes [41]. Meanwhile, through the analysis of surveys from 177 buildings in the United Kingdom, it was concluded that occupants were more tolerant to green buildings and even more in small buildings than in larger ones [42]. Yet, when analysing the predicted energy use and whether occupant behaviour is accounted in energy modeling simulations, it appears expected to verify a difference of more than $150 \%$ between the established lower and higher values that were used as reference. The parameters in which occupants had more impact, according to the author, were: ventilation rates, infiltration rates, equipment load, and occupancy schedule [43]. Finally, the direct and indirect impacts that occupants had in building performance associated with their presence is represented in Figure 4 [44].

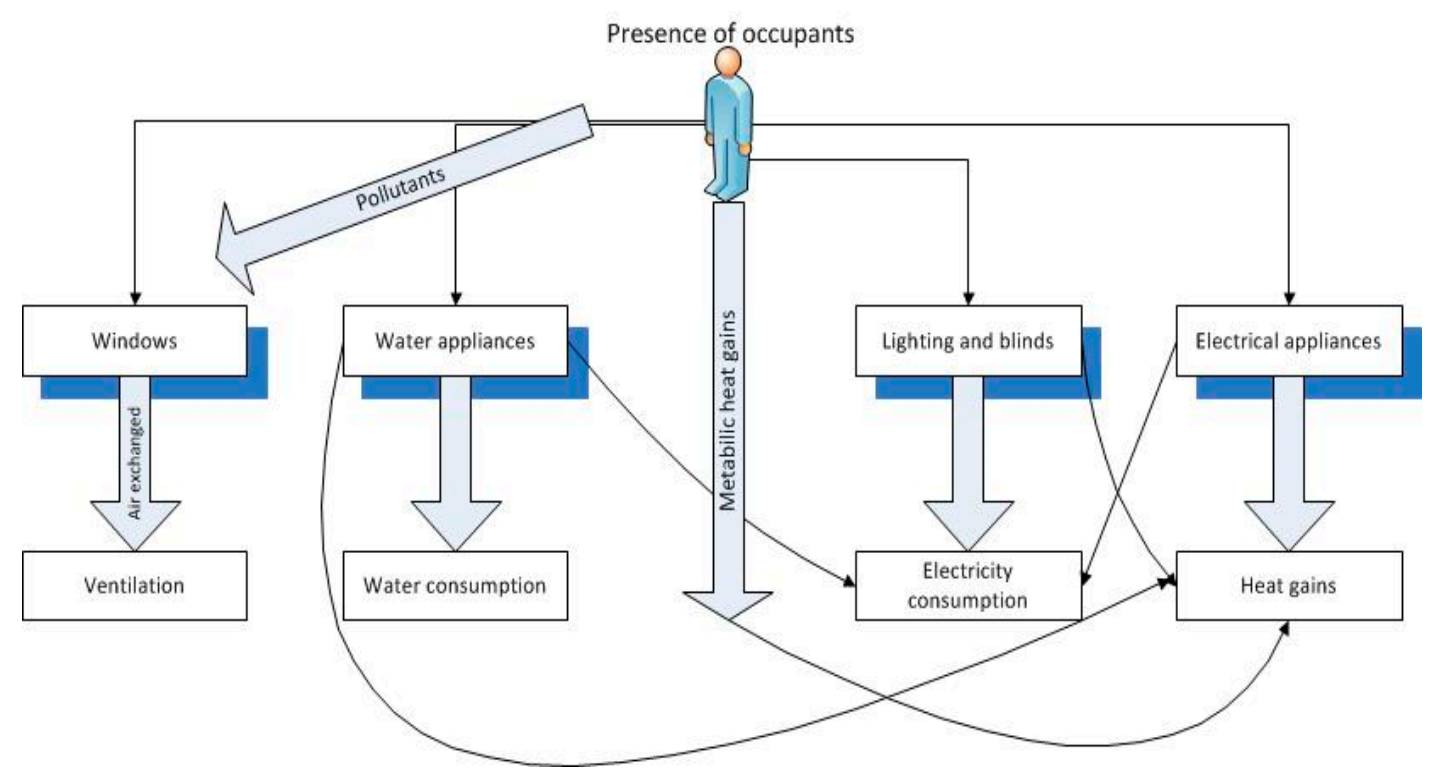

Figure 4. Direct and indirect impact in building resources by the presence of occupants [44].

\section{The Increasing Research Interest in Occupant Behaviour}

\subsection{Existing Occupancy Schedules}

Passing 2008, the interest of researchers in relation with occupant behaviour increased significantly. The way that occupants behaved with lighting and shading control systems, in office buildings in Austria was studied empirically and it was concluded that environmental systems were over-designed because they were dimensioned for levels of occupancy that rarely occur. This fact would imply a higher use of energy and by using lighting sensors and daylight-responsive dimming, it was possible to reduce $66 \%$ to $71 \%$ of the electrical uses [45]. Tanimoto et al. [46,47] compared and validated an existent schedule data algorithm, of $15 \mathrm{~min}$ activities of occupants, to a stochastic model by using the Markov chain in the on/off air-conditioning state of residential buildings and evaluated the linkage of occupants' behaviour in energy use that is related to demands of hot water, lighting, and power for electric appliances. The authors concluded that the conventional calculation procedure led to an overestimation of energy use. 


\subsection{Other Factors Affecting Energy Use}

After selecting 27 households to study the energy uses varying the location, type of household, age, number of occupants, income, energy resources, lighting systems, and appliances; a strong correlation between average annual electricity use and floor area was found in this study. Changing household appliances for more efficient ones and peak electricity use was also accounted; and, a change in the peak load to later night, due to a different life style, was referred [48].

In the meantime, Steemers and Yun [49] tried to establish the main factors, as represented in Figure 5, affecting energy performance in households, finding a strong relationship between energy use and the number of occupant, income, and age besides climate, building, and equipment; while economic and demographic factor did not seem to affect significant energy uses.

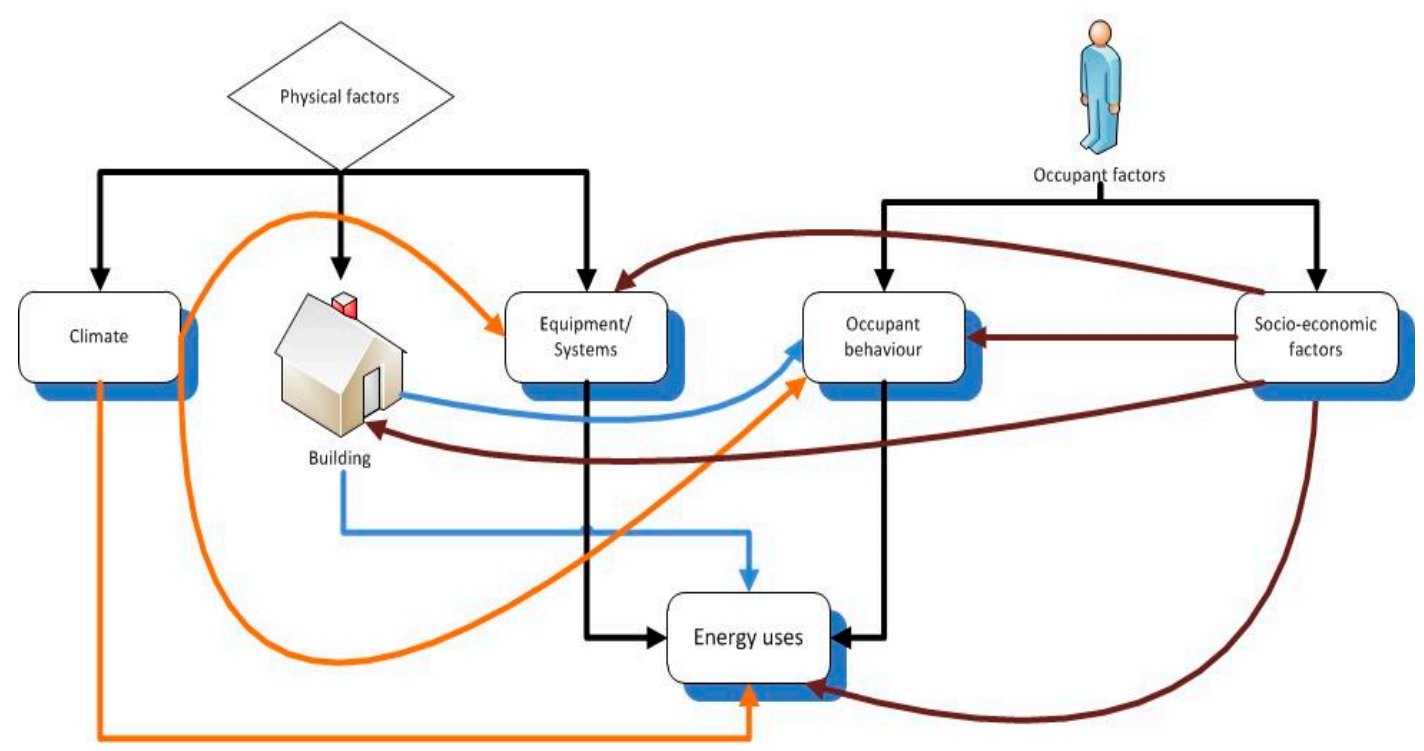

Figure 5. Key-direct and -indirect physical factor that influence occupant behaviour in domestic energy use [49].

\subsection{Indicators and Occupant Classification}

Using the method SHOCC, combined with a User Simulation of Space Utilization (USSU) model, which simulated the use of space and the movement among spaces, to the SHOCC mode. There were three levels of performance indicators that were related to behavioural occupancy studies defined by the authors: simplified, advanced user I, and advanced used II, which could be divided in energy, load, or comfort related [50]. Yun et al. [51] studied how user behaviour impacted the thermal performance of naturally ventilated buildings in summer. In order to do so, they developed a probabilistic occupant behaviour algorithm classifying occupants as active, medium and passive occupants in window opening, linking it with deterministic building physics models, based on the Monte Carlo method and the Markov chain. They could show that user behaviour had a significant influence in thermal performance.

Meanwhile, Dong and Andrews [52] referred the importance of a formal connection between behavioural patterns and building energy management systems. They developed and implemented algorithms for sensor-based modelling (collecting data related to lighting, acoustics, $\mathrm{CO}_{2}$, temperature, and relative humidity) and the prediction of user behaviour in smart buildings, connecting the behavioural patterns to building energy, and comfort management systems through simulation tools, such as EnergyPlus. The results indicated a $30 \%$ potential on energy savings without scarifying the IAQ. 


\subsection{Sustainable Programs and Design}

In 2010, researchers continued developing and deepening previous studies, such as the energy use in the residential sector and its relationship to the behaviour of occupants [53-55]; window-opening habits relating with IAQ control parameters [56]; behavioural patterns respecting energy use by means of a survey [57,58]; and, activating shading devices and its relationship with lighting, heat gains, thermal comfort, and consequently, with energy use [59,60].

More specifically, it developed a three case scenarios model for occupant behaviour and internal heat loads, evaluating the energy use and thermal comfort in line with the European energy performance building directive (EPBD) in different building's configuration (prestige, low-cost, and green building), slat angles $\left(0^{\circ}, 30^{\circ}, 80^{\circ}\right)$, and façade orientation $(\mathrm{N}, \mathrm{E}, \mathrm{S}, \mathrm{W})$, expressing results in terms of carbon emissions and concluding that the green building scenario had the highest comfort levels and it was the least affected by the influence of different occupant scenarios due to its effective solar protection and high thermal mass. Once again, carbon emissions associated with heating, lighting, and equipment were lower in the green building scenario and could be reduced by $50-70 \%$ when compared to a worst case scenario [61]. Then, in the context of sustainable behaviour, it was focused on the importance of social interaction, by means of a neighbourhood network as a mean of encouraging competition, comparison, and collaboration among community members in order for occupants to have better energy conservative behaviours [62].

Masoso and Grobler [63], after performing energy audits to six buildings in hot and dry climates, discussed the importance of evaluating the energy that is wasted in commercial buildings, during non-occupied hours that corresponds to $23 \%$ of all the wasted energy, due to inadequate energy behaviour by occupants, focusing on the importance of energy awareness campaigns. Another researcher concentrated their studies in the quality of energy and studied the occupant behaviour, from an energy use perspective, of heating and cooling while comparing it to the potential improvement of the building envelope. It was expected a reduction in energy use of $75 \%$ to $95 \%$ when combining occupant behavioural changes and building system improvements [64].

\subsection{The Relevance of Occupants Control in Building Features}

The reduced amount of studies related with office buildings when comparing to the residential sector, was emphasised by Arens [65]. Office buildings are more complex and therefore have more elements influencing energy use, such as owners, design professional, operation staff, and the occupants. He also referred the "new change of paradigm" where occupants are given the responsibility of managing certain aspects of the building. Yet, more information need to be provided related to the passive features and HVAC control systems, in order to pursue an energy efficiency approach. Moreover, there is a gap between the way that designers predict occupant behaviour and how they really operate because predictions were based in unrealistic schedules that cannot translate human behaviour in a plausible way [45].

Later in 2011, Mahdavi [66] discussed how occupants influence the performance of a building. Passively, just by their presence and depending on the type of activity occupants are performing, they could impact the hygro-thermal conditions of a building and its acoustics. In an active way, occupants had control of elements in a building, such as lighting, shades, windows, radiators, and therefore, occupants had a huge influence in energy use. Furthermore, the lack of additional consistent relationships between control actions and environmental (indoor and outdoor) conditions could provide more information on occupant behaviour to incorporate in building simulations. Therefore, he developed a model that was based on observational data divided by Events and States, regarding occupancy presence and actions in buildings. As a conclusion, the author identified three vantage points by accounting occupants as tool occupants, as modelled agents (with their presence and behaviour), and as beneficiaries of predicted building performance by deepening the knowledge of the complex processes that are affecting occupants. 
A nonlinear model predictive control (NMPC) to a test bed house in a real-time framework was implemented by Dong et al. [67], where weather forecasting and occupant behaviour was integrated, allowing for savings in cooling energy of around $18 \%$ and suggesting that this method can save additional energy when combined with real-time information. Meanwhile, a stochastic model together with a survey was used to understand how occupants behave towards their environment. The majority of occupants' answers were unconsciously based on their own habits and past influences, their surroundings, and other occupants [68]. Then, after developing a numerical model with dynamic occupancy it was possible to conclude that the more occupants had control over the energy use, the more energy would be used [69]. Finally, an investigation was conducted in order to understand how the employees of a large company perceived the use of energy and how their behaviour would influence the energy use, by means of a survey and statistical analysis of the results according to age, gender, years of employment, etc. The results showed that energy waste was related with lack of information and the misbehaviour in energy use [7].

\section{Real Energy Use}

\subsection{Real Occupant Behaviour}

Fabi et al. [70], in 2013, developed a probabilistic methodology that accounts with occupants' realistic behaviour related with building controls, classifying occupants as: passive, medium and active heating control occupants and Hong et al. [71] classified three types of energy impact occupant behaviour: austerity, standard, and wasteful; modelling with EnergyPlus, with energy management system (EMS) in EnergyPlus and by modifying the EnergyPlus source code in three different cities in the United States; concluding that the austerity type would save $50 \%$ energy while the wasteful would spend additional $89 \%$, when compared to the standard one.

Moreover, occupants tend to switch on the lights, in office buildings, when daylight level frequencies were lower than 300 lux. It was verified that, in $83 \%$ of the monitored time, the lights were kept on. Against of what other researchers studied, the authors supported that occupants were not inclined to activate shading control when experiencing sudden solar radiation variations. However, daylight glare probability, index, and workplane illuminance, as well as transmitted solar radiation had more correlation with the activation of shading [72].

A perspective of how interactive and social-media technologies may influence the way occupants use energy, was underlined in the fact that occupant's values affect the way individuals and communities decide and behave. Therefore, in order to communicate information that motivates a change in behaviour, their values had to be taken into account [73].

After studying 1628 households in the United States, it was found that occupants over 55 or from 19 to 35-year-old consumed less electricity and occupants who had pets tended to use more electricity. It also found no strong correlation among the use of energy and building age, income, or ownership [6]. Meanwhile, Wei et al. [74] described the creation of a research project called eViz, in the United Kingdom, which aimed to reduce energy use for heating purpose by using visualization on mobile devices to drive occupants as energy efficiently aware.

\subsection{IEA Annexes 53 and 66}

Understanding the relevance of knowing how the behaviour of occupants affects energy use in a building led researchers to elaborate the final report "Annex 53" for the Programme on Energy in Buildings and Communities (EBC), related with occupant behaviour and modeling, for the International Energy Agency (IEA), in November 2013. In this report, driving forces were defined as energy-related occupant behaviour.

These driving forces referred to parameters that have influence on the way occupants interact with buildings and its control systems; and, may be from an external or internal source, where the first were connected to the building and building equipment properties, time, and physical environment; 
and, the second one related to biological, psychological, and social aspects. Table 1 represents what driving forces influence occupant behaviour when using energy in cooling, heating, ventilation (including window operation), lighting, domestic hot water (DHW), appliances, and cooking [75].

In the same month, November 2013, the IEA approved the "Annex 66" project, "Definition and Simulation of Occupant Behaviour in Buildings", which aimed specifically to understand, model, and quantify how occupant behave inside buildings and the impact they had in energy use, as well as in indoor environmental quality (IEQ) [76]. The Annex 66 project will be developed and reported until the end of 2017 [77], and it is divided in five energy-related research subtasks that are represented in Table 2.

Table 1. Energy-related occupant behaviour, according to International Energy Agency (IEA) [75].

\begin{tabular}{ccc}
\hline Internal Driving Forces & \\
\hline Occupant related & Psychological & $\begin{array}{c}\text { Expectations and needs of comfort } \\
\text { lifestyle and habits } \\
\text { environmental awareness, } \ldots \\
\text { Interaction with other individuals } \\
\text { family composition } \\
\text { Clothing age, gender and } \\
\text { health activity, ... }\end{array}$ \\
\hline Biological & Physical environment & $\begin{array}{c}\text { Light and solar radiation } \\
\text { temperature and humidity } \\
\text { air rates and wind speed, } \ldots \\
\text { Type of control }\end{array}$ \\
Building & availability and accessibility \\
\hline & Time & $\begin{array}{c}\text { Duration temperature and } \\
\text { humidity air rates, ... }\end{array}$ \\
\hline
\end{tabular}

Table 2. Energy-related sub-tasks according to IEA [77].

\begin{tabular}{|c|c|c|c|}
\hline $\begin{array}{l}\text { Energy-Related } \\
\text { Sub-Tasks on } \\
\text { Occupant Behaviour }\end{array}$ & Occupant Models & Description & \\
\hline A & Movement and presence & $\begin{array}{l}\text { Standardize occupant movement and } \\
\text { presence by means of a simulation } \\
\text { methodology and definition }\end{array}$ & \multirow{3}{*}{ 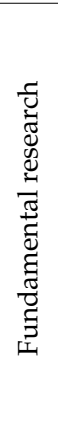 } \\
\hline B & Action in residential buildings & $\begin{array}{l}\text { Standardize occupant action behaviour } \\
\text { simulation, systematic measurement } \\
\text { approach, and modeling and validation } \\
\text { methodology in residential buildings }\end{array}$ & \\
\hline $\mathrm{C}$ & Action in commercial buildings & $\begin{array}{l}\text { Standardize occupant action behaviour } \\
\text { simulation, systematic measurement } \\
\text { approach, and modeling and validation } \\
\text { methodology in commercial buildings }\end{array}$ & \\
\hline $\mathrm{D}$ & $\begin{array}{c}\text { Integration of occupant } \\
\text { behaviour definition and models } \\
\text { with current building } \\
\text { energy modeling programs }\end{array}$ & $\begin{array}{l}\text { Deliver software modules and XML } \\
\text { framework schemes related with } \\
\text { occupant behaviour }\end{array}$ & 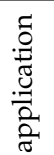 \\
\hline E & $\begin{array}{l}\text { Building design and } \\
\text { operations applications }\end{array}$ & $\begin{array}{l}\text { Provide case studies that enable the } \\
\text { verification of the new occupant } \\
\text { behaviour definition and models }\end{array}$ & 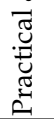 \\
\hline
\end{tabular}

The way that occupants behave influences the energy performance of a building, and consequently, energy costs and impacts to the environment. This fact is illustrated in Figure 6, according to the IEA. 


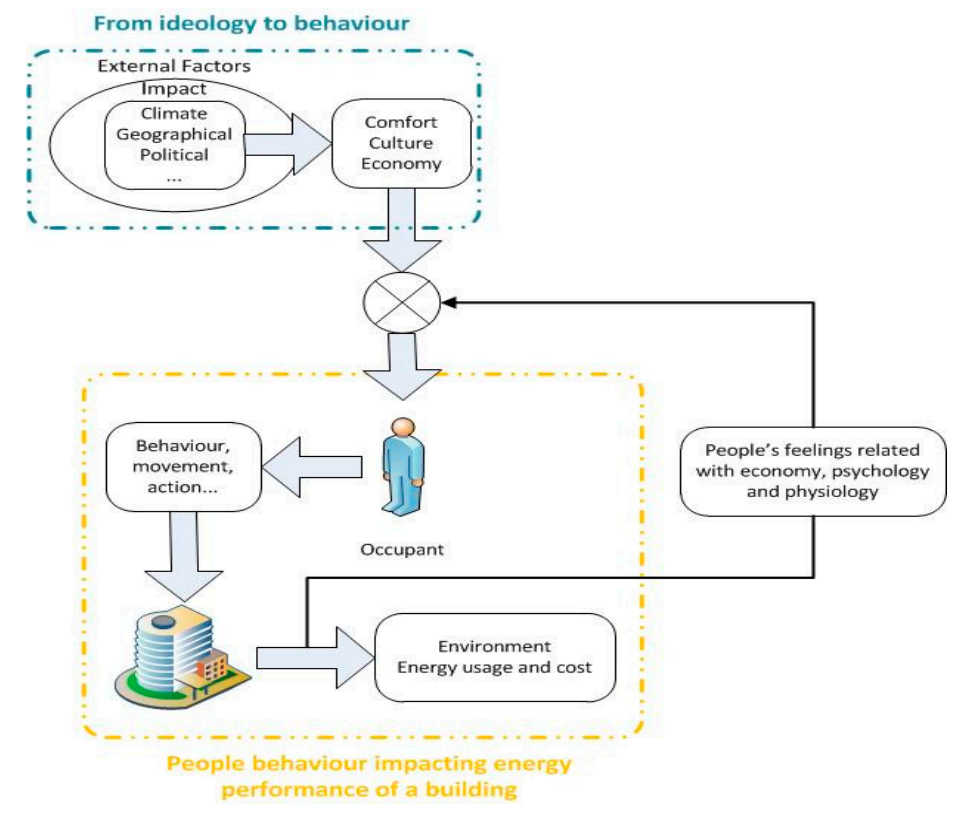

Figure 6. Occupant's relationship with buildings.

With the development of the IEA EBC Annex 66, new behavioural models and software models will be created that may allow for the integration with existing energy modeling software. Nevertheless, reliable tools may be generated to aid professionals with real time solutions that will promote the increase in the quality of design, operation, and energy retrofit evaluation in buildings [78].

\subsection{Energy Performance in Buildings}

In 2014, de Wilde [12] developed a pilot study to identify the gap on energy performance of a building between design and operational stages. There were three different aspects that may contribute to the previous differences. The first was related to incongruences among energy modelings in the design stage and the energy measurements during the operational period; discrepancies concerning equipment learning approaches and real measurements; and finally, the third divergence was linked to the energy rating systems where the design compliance was always different from the one that is displayed in the energy certificate. As conclusion, the author focused on the fact that the differences in the energy performance of a building vary with external conditions and time steps of the energy measurements. Moreover, it was suggested a change in the way building engineering is performed nowadays in order to address the existing energy performance gap.

Another researcher focused their studies in relating the energy use in an office building from a perspective of comfort control. The test bed study was based on the installation of sensors, not only to measure comfort parameter, such as temperature, illuminance, $\mathrm{CO}_{2}$ levels, etc.; but also, to wireless sensors to detect occupant presence and movement. Results showed that it was possible to achieve savings up to $14 \%$ and $18 \%$ in heating and cooling demands, respectively, when the temperature was controlled locally in the office and compared to the energy use at the design stage. Nevertheless, if compared to the operational phase, it was expected a saving potential of around $30 \%$ in heating and up to $38 \%$ in cooling. The author defined occupant behaviour as "the presence of occupants in workplace location and the action occupants take (or not take) to influence their indoor environment" [79].

\section{Recent Research}

Since 2015, researchers intensified their studies regarding occupant behaviour, from which the ones that are considered as new achievements or approaches to energy-related occupant behaviour are mentioned next in this paper. 
Buso et al. [80] studied the impact of occupant behaviour in different building envelope design, concluding that, with the increase of thermal mass and the reduction of envelope's transparent area, energy performance was not so affected by the fluctuations in occupants' behaviour. This fact was applied to locations with larger seasonal differences. Then, D'Oca et al. [81,82], proposed a data mining, Knowledge Discovery in Databases (KDD) process, learning frameworks for window opening and occupancy presence in 16 offices naturally ventilated. Moreover, their aim was to obtain a valid occupancy schedule, by applying cluster analysis that could contemplate occupant movement and presence in offices.

Following the Annex 66 project and the understanding that the existence of a reliable energy-related behavioural model was inexistent, Hong et al. $[83,84]$ suggested a DNAs (Drivers, Needs, Actions and Systems) framework, as represented in Table 3, and developed a XML (eXtensible Markup Language) schema, with the aim of normalize energy-related occupant behaviour in buildings.

Table 3. DNA framework $[83,84]$.

\begin{tabular}{cccc}
\hline Drivers & Needs & Actions & Systems \\
\hline Occupant & Physical & Movement & HVAC \\
Building & Non Physical & Activating or & Light \\
Environment & Comfort & deactivating Systems & Equipment \\
Time & Biological & Inaction & Shades and blinds \\
Systems & & Discomfort & Windows \\
& & & $\ldots$ \\
\hline
\end{tabular}

With the previous framework, it was the intention of the authors to present a reliable answer that might address the most relevant gaps that are found in literature, such as: differences between predicted and real energy uses; real and modelled occupant behaviour; systems performances; etc. Moreover, the DNAs framework, with its recurrent use, would become a standardized tool for building information modelling (BIM) allowed for building designers to account with occupant behaviour from early stages of the construction process.

Then, in the context of "green buildings", Khashe et al. [85] analysed the influence a sustainability certification program brand, such as LEED, had in the behaviour of occupants. The authors referred that just by having a "green building" brand does not mean that the building is a "green building". The concepts of sustainable design will only have real time effects when properly used by occupants. Nevertheless, LEED branding influences the environmental awareness of occupants and how they use light, by preferring natural to artificial light, as well as promoting waste reduction. Once again, the relevance of making occupants active participants in saving energy strategies, by making them aware of their contribution and the responsibility in the way that energy is used in buildings, and promoting communication between them, was referred in the Darby et al. [86] study. The significance of "green" tools and brands was also mentioned as a positive catalyst to reduce energy use and increase occupants' awareness.

Subsequently, and in line with the concepts mentioned in the point 3.2, the Human and Building Interaction Toolkit (HABIT) was introduced by Lagevin et al. [87] as a simulator of thermal comfort and adaptive occupant behaviour by simulating an agent-based behaviour model (ABM) in MATLAB, using Building Controls Virtual Test Bed (BCVTB), and model the whole building energy in EnergyPlus. The application of this toolkit may represent a potential of up to $28 \%$ energy savings in the HVAC system.

Nevertheless, the importance of incorporating social science with energy use and turn energy-related studies in an interdisciplinary field was focused by Sovacool et al. [88]. They underlined the recommendation of a deeper understanding and interconnection in these fields. Other authors developed studies not only to deepen the knowledge but also to develop new research studies in order to support the different subtasks that are defined by the IEA, represented in Table 2, of the predictability of presence and movement of occupant in buildings [89-91]; window opening behaviour 
in the residential sector [92-94] and light switching action [95]; indoor comfort and how it affects occupant behaviour and energy use [94,96,97]; energy-related occupant behaviour surveys [98,99]; etc.

Finally, Hong et al. [13] discussed the ten main questions affecting occupant behaviour. These questions involve issues such as: monitoring the interactions of occupants in buildings and their implications in use of energy; improving building performance simulation (BPS) and behavioural programs, using behaviour models applications; implementation of behavioural models in BPS; promote social methods to evaluate and improve the occupant interaction in buildings; and determine future research by analysing the results achieved. Moreover, as a result of the Annex 66 programme, it was highlighted the need of deepening the technical knowledge of the psychological and cultural aspects related with occupant behaviour, as well as the machine-learned comfort preferences of occupants that will enable an optimization of the control systems in buildings [78].

\section{Discussion}

This paper reviewed key driving studies, defined as milestones, from 1951 to 2016 that added new approaches to their conclusions and/or studies in the energy-related occupant behaviour discipline. Furthermore, this study identifies future fields of opportunity for research. Figure 7 depicts the chronological evolution of the main milestones reviewed in this investigation, as well as the impacted energy uses in a building.

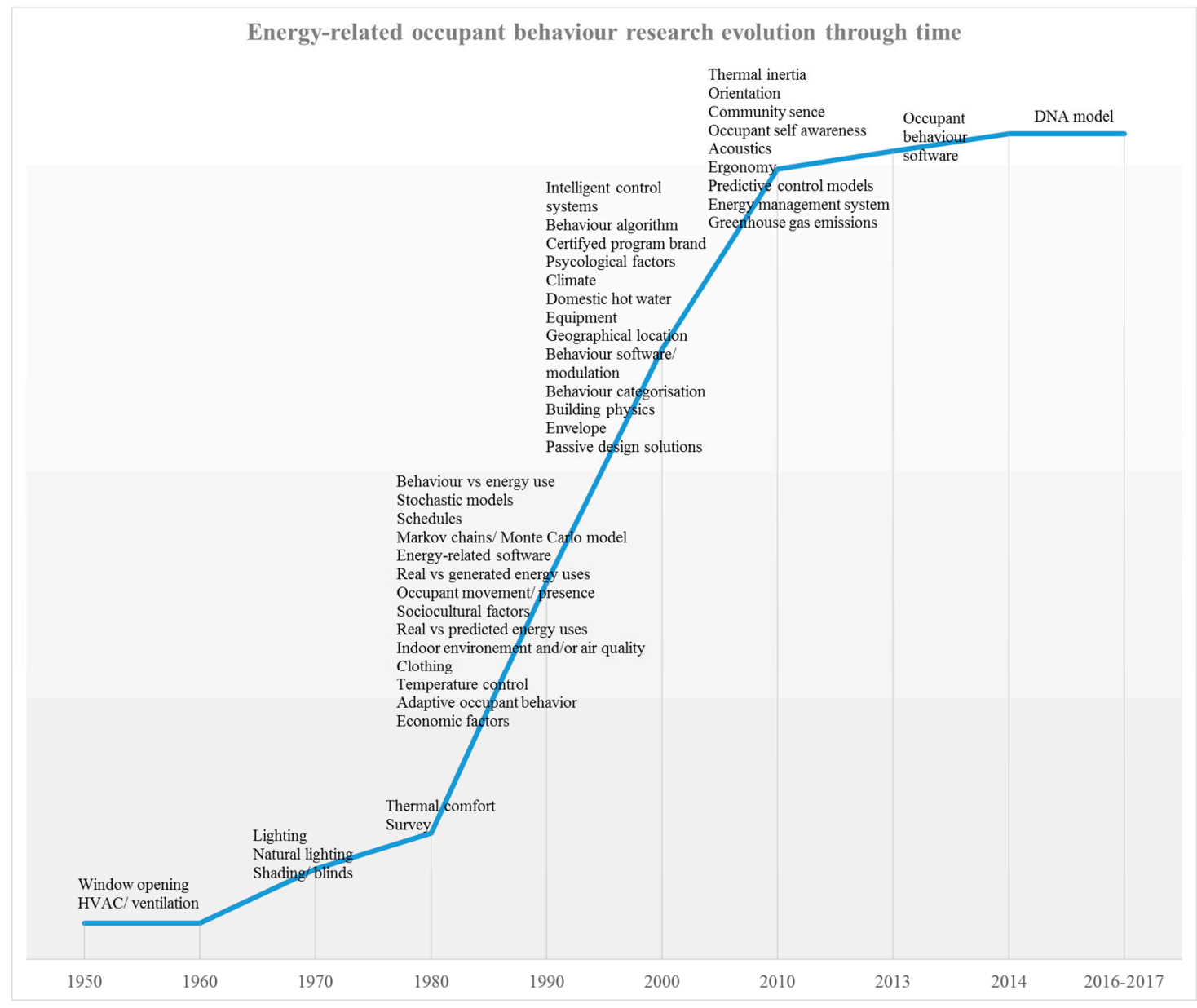

Figure 7. Chronological milestones in energy-related occupant behaviour since 1951.

In the last 65 years, the way that occupants behave when interacting with building systems and features, as well as their implication in the energy performance of buildings as a whole, has been 
as matter of increase research. The difference between real energy use and the predicted data during the design stage made the researchers aware of the urgency to understand the reason for this deviation. The relevance of occupants' actions in buildings was being underestimated during building energy predictions. Occupants were used as mere thermal sources and the interaction that they had inside buildings was ignored.

Occupants may have influence in the heating and cooling functions by incorrect use of controls, shading and window operation, non-optimize lighting, discomfort, movement, and activity. Similarly, in terms of lighting, occupants may affect energy use by incorrect use of controls, shading and window operation, discomfort, movement, and activity. DHW and equipment energy use is affected by occupants fundamentally due to its incorrect use.

Further studies point to the need of understanding the relationship between occupant energy-related behaviour and its implications to the energy management system in a building more in depth. Moreover, during the design phase, it is fundamental to account with better occupant behaviour data in order to improve operational efficiency and comfort levels. Nevertheless, surpassing the energy performance gap is essential either in the design stage as well as during the operational one.

Another aspect that needs further development is the quality of the measurements and data [100], as well as the need of additional reliable models to simulate occupant behaviour and actions, and a standard framework to be able to integrate building simulation programs [101]. There is also the need of supplementary methods to relate socio-economic trends and new technology developments.

Moreover, this paper suggests additional and more detailed studies of energy-related occupant behaviour in office and commercial buildings, as well as in the industrial sector, due to the complexity of its systems.

\section{Conclusions}

The purpose of this paper was to chronologically provide an overall review of the main key points in energy-related occupant behaviour research, the main conclusions, and the most relevant gaps. Due to the complexity and the variety of the different aspects affecting energy-related occupant behaviour, a more detailed and specific review would be recommended to each one of the different aspects affecting occupants' behaviour when related with energy. One of the most relevant gaps that was identified by researchers was the difference between real energy performance in a building and the one predicted at the design stage. This gap is due to the fact that real occupant behaviour is not being taken into account at the design stage and the schedules that are used in energy simulation programs are based on theoretical values that do not reflect the real ones. Furthermore, energy rating systems use theoretical schedules as a form of normalizing results, which leads to differences in real building energy use. Alternative methods need to be developed to address this issue. The best way to account and minimize occupant energy-related behaviour is to act instantaneously and make them aware of the implications of their actions in a real-time performance of a building. Moreover, occupants should be well informed of the best practices when dealing with building systems, such as lighting, HVAC, equipment, DHW, etc. Each building should be provided with a technical manual where occupants would be able to know and understand its main components, their interactions and a user guide towards a better building performance. The key element to excellence in building performance either energetically or environmentally is the one that has been neglected in each one of the existing rating systems, which is: Occupant Behaviour.

Author Contributions: This project is L.A.'s PhD study. V.T. and K.L. are her supervisors. L.A. initiated the idea with the support from V.T. and K. L. We have collected, analyzed and validate the data.

Funding: The authors wish to acknowledge the financial support from the Australian Research Council (ARC) Discovery Project under grant number DP150101015.

Conflicts of Interest: The authors declare no conflict of interest. 


\section{References}

1. International Energy Agency. Modernising Building Energy Codes to Secure Our Global Energy Future; International Energy Agency: Paris, France, 2013; p. 8.

2. IEA. Australia: Balances for 2014. International Energy Agency. 2014. Available online: https://www.iea. $\mathrm{org} /$ statistics/statisticssearch/report/ (accessed on 6 december 2016).

3. International Energy Agency. Energy Efficiency Market Report 2016; International Energy Agency (IEA): Paris, France, 2016; p. 17.

4. Norford, L.K.; Socolow, R.H.; Hsieh, E.S.; Spadaro, G.V. Two-to-one discrepancy between measured and predicted performance of a 'low-energy' office building: Insights from reconciliation based on the DOE-2model. Energy Build. 1994, 21, 121-131. [CrossRef]

5. Branco, G.; Lachal, B.; Gallinelli, P.; Weber, W. Predicted versus observed heat consumption of a low energy multifamily complex in Switzerland based on long-term experimental data. Energy Build. 2004, 36, 543-555. [CrossRef]

6. Kavousian, A.; Rajagopal, R.; Fischer, M. Determinants of residential electricity consumption: Using smart meter data to examine the effect of climate, building characteristics, appliance stock, and occupants' behavior. Energy 2013, 55, 184-194. [CrossRef]

7. Nisiforou, O.A.; Poullis, S.; Charalambides, A.G. Behaviour, attitudes and opinion of large enterprise employees with regard to their energy usage habits and adoption of energy saving measures. Energy Build. 2012, 55, 299-311. [CrossRef]

8. Dick, J.; Thomas, D. Ventilation research in occupied houses. J. Inst. Heat. Vent. Eng. 1951, 19, $279-305$.

9. Fritsch, R.; Kohler, A.; Nygardferguson, M.; Scartezzini, J.L. A stochastic model of user behaviour regarding ventilation. Build. Environ. 1990, 25, 173-181. [CrossRef]

10. Lutzenhiser, L. Social and behavioral aspects of energy use. Annu. Rev. Energy Environ. 1993, 18, $247-289$. [CrossRef]

11. Baker, N.; Standeven, M. A behavioural approach to thermal comfort assessment. Int. J. Sol. Energy 1997, 19, 21-35. [CrossRef]

12. De Wilde, P. The gap between predicted and measured energy performance of buildings: A framework for investigation. Autom. Constr. 2014, 41, 40-49. [CrossRef]

13. Hong, T.; Yan, D.; D'Oca, S.; Chen, C.-F. Ten questions concerning occupant behavior in buildings: The big picture. Build. Environ. 2017, 114, 518-530. [CrossRef]

14. Brundrett, G. Ventilation: A behavioural approach. Energy Res. 1977, 1, 289-298. [CrossRef]

15. Hunt, D.R.G. The use of artificial lighting in relation to daylight levels and occupancy. Build. Environ. 1979, 14, 21-33. [CrossRef]

16. Rea, M.S. Window blind occlusion: A pilot study. Build. Environ. 1984, 19, 133-137. [CrossRef]

17. Weihl, J.S.; Gladhart, P.M. Occupant behavior and successful energy conservation: Findings and implications of behavioral monitoring. In ACEEE Summer Study on Energy Efficiency in Buildings, Human Dimensions; ACEEE: Washington, DC, USA, 1990.

18. Emery, A.F.; Gartland, L.M. Quantifying Occupant Energy Behavior Using Pattern Analysis Techniques; California Digital Library: Oakland, CA, USA, 1991; pp. 47-59.

19. Newsham, G. Occupant movement and the thermal modelling of buildings. Energy Build. 1992, 18, 57-64. [CrossRef]

20. De Dear, R.J.; Brager, G.S. Thermal comfort in naturally ventilated buildings: Revisions to ASHRAE Standard 55. Energy Build. 2002, 24, 549-561. [CrossRef]

21. Bluyssen, M.; de Oliveira Fernandes, E.; Groes, L.; Clausen, G.; Fanger, P.O.; Valbyorn, O.; Bernhard, C.A.; Roulet, C.A. European indoor air quality audit project in 56 office buildings. Indoor Air 1996, 6, 221-238. [CrossRef]

22. Wilhite, H.; Nakagami, H.; Masuda, T.; Yamaga, Y.; Haneda, H. A cross-cultural analysis of household energy use behaviour in Japan and Norway. Energy Policy 1996, 24, 795-803. [CrossRef]

23. Maniccia, D.; Rutledge, B.; Rea, M.S.; Morrow, W. Occupant use of manual lighting controls in private offices. J. Illum. Eng. Soc. 1999, 28, 42-56. [CrossRef]

24. Garg, V.; Bansal, N.K. Smart occupancy sensors to reduce energy consumption. Energy Build. 2000, 32, 81-87. [CrossRef] 
25. Foster, M.; Oreszczyn, T. Occupant control of passive systems: The use of Venetian blinds. Build. Environ. 2001, 36, 149-155. [CrossRef]

26. Iwashita, G.; Akasaka, H. The effects of human behavior on natural ventilation rate and indoor air environment in summer-A field study in southern Japan. Energy Build. 1997, 25, 195-205. [CrossRef]

27. Nicol, J. Characterising occupant behaviour in buildings: Towards a stochastic model of occupant use of windows, lights, blinds, heaters and fans. In Proceedings of the Seventh International IBPSA Conference, Rio de Janeiro, Brazil, 13-15 August 2001; Volume 2, pp. 1073-1078.

28. McCartney, K.J.; Nicol, J.F. Developing an adaptive control algorithm for Europe. Energy Build. 2002, 34, 623-635. [CrossRef]

29. Guillemin, A.; Molteni, S. An energy-effcient controller for shading devices self-adapting to the user wishes. Build. Environ. 2002, 37, 1091-1097. [CrossRef]

30. Al-Mumin, A.; Khattab, O.; Sridhar, G. Occupants' behavior and activity patterns influencing the energy consumption in the Kuwaiti residences. Energy Build. 2003, 35, 549-559. [CrossRef]

31. Stokes, M.; Rylatt, M.; Lomas, K. A simple model of domestic lighting demand. Energy Build. 2004, 36, 103-116. [CrossRef]

32. Reinhart, C.F. Lightswitch-2002: A model for manual and automated control of electric lighting and blinds. Sol. Energy 2004, 77, 15-28. [CrossRef]

33. Newsham, G.; Arsenault, C.; Veitch, J.; Tosco, A.; Duval, C. Task lighting effects on office worker satisfaction and performance, and energy efficiency. J. Illum. Eng. Soc. N. Am. 2005, 1, 7-26. [CrossRef]

34. Turner, C. LEED Building Performance in the Cascadia Region: A Post Occupancy Evaluation Report; Cascadia Region Green Building Council: Portland, OR, USA, 2006.

35. Tanimoto, J.; Hagishima, A. State transition probability for the Markov model dealing with on/off cooling schedule in dwellings. Energy Build. 2005, 37, 181-187. [CrossRef]

36. Herkel, S.; Knapp, U.; Pfafferott, J. A preliminary model of user behaviour regarding the manual control of windows in office buildings. In Proceedings of the Ninth International IBPSA Conference, Montréal, QC, Canada, 15-18 August 2005; Volume 49, pp. 1-6.

37. Mysen, M.; Berntsen, S.; Nafstad, P.; Schild, P.G. Occupancy density and benefits of demand-controlled ventilation in Norwegian primary schools. Energy Build. 2005, 37, 1234-1240. [CrossRef]

38. Bourgeois, D. Detailed Occupancy Prediction, Occupancy-Sensing Control and Advanced Behavioural Modelling Within Whole-Building Energy Simulation. Ph.D. Thesis, Faculté des Études Supérieures de l'Université Laval, Quebec, QC, Canada, 2005.

39. Bourgeois, D.; Reinhart, C.; Macdonald, I. Adding advanced behavioural models in whole building energy simulation: A study on the total energy impact of manual and automated lighting control. Energy Build. 2006, 38, 814-823. [CrossRef]

40. Emery, A.F.; Kippenhan, C.J. A long term study of residential home heating consumption and the effect of occupant behavior on homes in the Pacific Northwest constructed according to improved thermal standards. Energy 2006, 31, 677-693. [CrossRef]

41. Karlsson, F.; Rohdin, P.; Persson, M.-L. Measured and predicted energy demand of a low energy building: Important aspects when using building energy simulation. Build. Serv. Eng. Res. Technol. 2007, 28, $223-235$. [CrossRef]

42. Leaman, A.; Bordass, B. Are users more tolerant of 'green' buildings? Build. Res. Inf. 2007, 35, 662-673. [CrossRef]

43. Clevenger, C.M.; Haymaker, J.R. The impact of the building occupant on energy modeling simulations. In Proceedings of the Joint International Conference on Computing and Decision Making in Civil and Building Engineering, Montreal, QC, Canada, 14-16 June 2006.

44. Page, J. Simulating Occupant Presence and Behaviour in Buildings. Ph.D. Thesis, Faculté de L'Environnement Naturel, Architectural et Construit Laboratoire D'Énergie Solaire et Physique du Bâtiment, Lausanne, Switzerland, 2007.

45. Mahdavi, A.; Mohammadi, A.; Kabir, E.; Lambeva, L. Occupants' operation of lighting and shading systems in office buildings. J. Build. Perform. Simul. 2008, 1, 57-65. [CrossRef]

46. Tanimoto, J.; Hagishima, A.; Sagara, H. A methodology for peak energy requirement considering actual variation of occupants' behavior schedules. Build. Environ. 2008, 43, 610-619. [CrossRef] 
47. Tanimoto, J.; Hagishima, A.; Sagara, H. Validation of probabilistic methodology for generating actual inhabitants' behavior schedules for accurate prediction of maximum energy requirements. Energy Build. 2008, 40, 316-322. [CrossRef]

48. Yohanis, Y.G.; Mondol, J.D.; Wright, A.; Norton, B. Real-life energy use in the UK: How occupancy and dwelling characteristics affect domestic electricity use. Energy Build. 2008, 40, 1053-1059. [CrossRef]

49. Steemers, K.; Yun, G.Y. Household energy consumption: A study of the role of occupants. Build. Res. Inf. 2009, 37, 625-637. [CrossRef]

50. Hoes, P.; Hensen, J.L.M.; Loomans, M.G.L.C.; de Vries, B.; Bourgeois, D. User behavior in whole building simulation. Energy Build. 2009, 41, 295-302. [CrossRef]

51. Yun, G.Y.; Tuohy, P.; Steemers, K. Thermal performance of a naturally ventilated building using a combined algorithm of probabilistic occupant behaviour and deterministic heat and mass balance models. Energy Build. 2009, 41, 489-499. [CrossRef]

52. Dong, B.; Andrews, B. Sensor-based occupancy behavioral pattern recognition for energy and comfort management in intelligent buildings. In Proceedings of the Building Simulation 2011, Glasgow, UK, 27-30 July 2009.

53. Gram-Hanssen, K. Residential heat comfort practices: Understanding users. Build. Res. Inf. 2010, 38, $175-186$. [CrossRef]

54. Guerra Santin, O. Actual Energy Consumption in Dwellings the Effect of Energy Performance Regulations and Occupant Behaviour; Ebrary, I., Ed.; Proefschrift-Technische Universiteit Delft: Amsterdam, The Netherlands, 2010.

55. Larsen, T.S.; Knudsen, H.N.; Kanstrup, A.M.; Christiansen, E.T.; Gram-Hanssen, K.; Mosgaard, M.; Brohus, H.; Heiselberg, P.K.; Rose, J. Occupants Influence on the Energy Consumption of Danish Domestic Buildings; Aalborg Universitet: Aalborg, Denmark, 2010.

56. Dutton, S.; Shao, L. Window opening behaviour in a naturally ventilated school. In Proceedings of the Fourth National Conference of IBPSA-USA, New York City, NY, USA, 11-13 August 2010.

57. Ek, K.; Söderholm, P. The devil is in the details: Household electricity saving behavior and the role of information. Energy Policy 2010, 38, 1578-1587. [CrossRef]

58. Crosbie, T.; Baker, K. Energy-efficiency interventions in housing: Learning from the inhabitants. Build. Res. Inf. 2010, 38, 70-79. [CrossRef]

59. Haldi, F.; Robinson, D. Adaptive actions on shading devices in response to local visual stimuli. J. Build. Perform. Simul. 2010, 3, 135-153. [CrossRef]

60. Daum, D.; Morel, N. Assessing the total energy impact of manual and optimized blind control in combination with different lighting schedules in a building simulation environment. J. Build. Perform. Simul. 2010, 3, 1-16. [CrossRef]

61. Roetzel, A.; Tsangrassoulis, A.; Dietrich, U.; Busching, S. On the influence of building design, occupants and heat waves on comfort and greenhouse gas emissions in naturally ventilated offices. A study based on the EN 15251 adaptive thermal comfort model in Athens, Greece. Build. Simul. 2010, 3, 87-103. [CrossRef]

62. Bartram, L.; Rodgers, J.; Muise, K. Chasing the Negawatt: Visualization for sustainable living. IEEE Comput. Graph. Appl. 2010, 30, 8-14. [CrossRef] [PubMed]

63. Masoso, O.T.; Grobler, L.J. The dark side of occupants' behaviour on building energy use. Energy Build. 2010, 42, 173-177. [CrossRef]

64. Schweiker, M.; Shukuya, M. Comparative effects of building envelope improvements and occupant behavioural changes on the exergy consumption for heating and cooling. Energy Policy 2010, 38, $2976-2986$. [CrossRef]

65. Arens, E. Behavior and Buildings; Newsletter of the Center for the Built Environment at the University of California: Berkeley, CA, USA, 2010.

66. Mahdavi, A. The human dimension of building performance simulation. In Proceedings of the 12th Conference of International Building Performance Simulation Association, Sydney, Australia, 14-16 November 2011.

67. Dong, B.; Lam, K.P.; Neuman, C.P. Integrated building control based on occupant behavior pattern detection and local weather forecasting. In Proceedings of the 12th Conference of International Building Performance Simulation Association, Sydney, Australia, 14-16 November 2011; p. 8. 
68. Bluyssen, P.M.; Aries, M.; van Dommelen, P. Comfort of workers in office buildings: The European HOPE project. Build. Environ. 2011, 46, 280-288. [CrossRef]

69. Azar, E.; Menassa, C.C. Agent-based modeling of occupants and their impact on energy use in commercial buildings. J. Comput. Civ. Eng. 2012, 26, 506-518. [CrossRef]

70. Fabi, V.; Andersen, R.V.; Corgnati, S. Influence of occupant's heating set-point preferences on indoor environmental quality and heating demand in residential buildings. HVAC R Res. 2013, 19, 635-645.

71. Hong, T.; Lin, H.-W. Occupant Behavior: Impact on Energy Use of Private Offices; Ernest Orlando Lawrence Berkeley National Laboratory: Berkeley, CA, USA, 2013.

72. Da Silva, P.C.; Leal, V.; Andersen, M. Occupants interaction with electric lighting and shading systems in real single-occupied offices: Results from a monitoring campaign. Build. Environ. 2013, 64, 152-168. [CrossRef]

73. Burrows, R.; Johnson, H.; Johnson, P. Influencing Values, Attitudes and Behaviour via Interactive and Social-Media Technology: The Case of Energy Usage (Technical Report); University of Bath Online Publication Store: Bath, UK, 2013.

74. Wei, S.; Jones, R.; Goodhew, S.; De Wilde, P. Occupants' space heating behaviour in a simulation-intervention loop. In Proceedings of the 13th Conference of International Building Performance Simulation Association, Chambéry, France, 26-28 August 2013; pp. 1991-1998.

75. Polinder, H.; Schweiker, M.; der Aa, A.V.; Schakib-Ekbatan, K.; Fabi, V.; Andersen, R.; Morishita, N.; Wang, C.; Corgnati, S.; Heiselberg, P.; et al. Occupant Behavior and Modeling; Energy in Buildings and Communities; International Energy Agency: Paris, France, 2013; Volume 2.

76. IEA. IEA-EBC Annex 66-Definition and Simulation of Occupant Behaviour in Buildings. Energy in Buildings anc Communities Program. 2016. Available online: http:/ / www.annex66.org/ (accessed on 6 June 2016).

77. Yan, D.; Hong, T. EBC Annex 66 Text-Definition and Simulation of Occupant Behavior in Buildings; EBC-Energy in Buildings and Communities Programme; International Energy Agency: Paris, France, 2014.

78. Yan, D.; Hong, T.; Dong, B.; Mahdavi, A.; D'Oca, S.; Gaetani, I.; Feng, X. IEA EBC annex 66: Definition and simulation of occupant behavior in buildings. Energy Build. 2017, 156, 258-270. [CrossRef]

79. Zeiler, W.; Vissers, D.; Maaijen, R.; Boxem, G. Occupants' behavioural impact on energy consumption: 'Human-in-the-loop' comfort process control. Archit. Eng. Des. Manag. 2014, 10, 108-130. [CrossRef]

80. Buso, T.; Fabi, V.; Andersen, R.K.; Corgnati, S.P. Occupant behaviour and robustness of building design. Build. Environ. 2015, 94, 694-703. [CrossRef]

81. D'Oca, S.; Corgnati, S.; Hong, T. Data mining of occupant behavior in office buildings. Energy Procedia 2015, 78, 585-590. [CrossRef]

82. D'Oca, S.; Hong, T. Occupancy schedules learning process through a data mining framework. Energy Build. 2015, 88, 395-408. [CrossRef]

83. Hong, T.; D’Oca, S.; Turner, W.J.N.; Taylor-Lange, S.C. An ontology to represent energy-related occupant behavior in buildings. Part I: Introduction to the DNAS framework. Build. Environ. 2015, 92, 764-777. [CrossRef]

84. Hong, T.; D'Oca, S.; Taylor-Lange, S.C.; Turner, W.; Chen, Y.; Corgnati, S. An ontology to represent energy-related occupant behavior in buildings. Part II: Implementation of the DNAS framework using an XML schema. Build. Environ. 2015, 94, 196-205. [CrossRef]

85. Khashe, S.; Heydarian, A.; Gerber, D.; Becerik-Gerber, B.; Hayes, T.; Wood, W. Influence of LEED branding on building occupants' pro-environmental behavior. Build. Environ. 2015, 94, 477-488. [CrossRef]

86. Darby, H.; Elmualim, A.; Clements-Croome, D.; Yearley, T.; Box, W. Influence of occupants' behaviour on energy and carbon emission reduction in a higher education building in the UK. Intell. Build. Int. 2016, 8, 157-175. [CrossRef]

87. Langevin, J.; Wen, J.; Gurian, P.L. Quantifying the human-building interaction: Considering the active, adaptive occupant in building performance simulation. Energy Build. 2016, 117, 372-386. [CrossRef]

88. Sovacool, B.K.; Ryan, S.E.; Stern, P.C.; Janda, K.; Rochlin, G.; Spreng, D.; Pasqualetti, M.J.; Wilhite, H.; Lutzenhiser, L. Integrating social science in energy research. Energy Res. Soc. Sci. 2015, 6, 95-99. [CrossRef]

89. Kim, D.-W.; Ahn, K.-U.; Kim, K.-C.; Wilde, P.D.; Park, C.-S. Predictabilty of occupancy pattern in real-life cases. In Proceedings of the BS2015: 14th Conference of International Building Performance Simulation Association, Hyderabad, India, 7-9 December 2015.

90. Mahdavi, A.; Tahmasebi, F. Predicting people's presence in buildings: An empirically based model performance analysis. Energy Build. 2015, 86, 349-355. [CrossRef] 
91. Tahmasebi, F.; Mahdavi, A. The sensitivity of building performance simulation results to the choice of occupants' presence models: A case study. J. Build. Perform. Simul. 2017, 10, 625-635. [CrossRef]

92. Schakib-Ekbatan, K.; akici, F.Z.; Schweiker, M.; Wagner, A. Does the occupant behavior match the energy concept of the building?-Analysis of a German naturally ventilated office building. Build. Environ. 2015, 84, 142-150. [CrossRef]

93. Wei, S.; Xu, C.; Pan, S.; Su, J.; Wang, Y.; Luo, X.; Hassan, T.M.; Firth, S.; Fouchal, F.; Jones, R.; et al. Analysis of factors inuencing the modelling of occupant window opening behaviour in an office building in Beijing, China. In Proceedings of the IBPSA, Hyderabad, India, 7-9 December 2015.

94. Andersen, R.K.; Fabi, V.; Corgnati, S.P. Predicted and actual indoor environmental quality: Verification of occupants' behaviour models in residential buildings. Energy Build. 2016, 127, 105-115. [CrossRef]

95. Wang, C.; Yan, D.; Ren, X. Modeling individual's light switching behavior to understand lighting energy use of office building. Energy Procedia 2016, 88, 781-787. [CrossRef]

96. Serghides, D.K.; Chatzinikola, C.K.; Katafygiotou, M.C. Comparative studies of the occupants' behaviour in a university building during winter and summer time. Int. J. Sustain. Energy 2015, 34, 528-551. [CrossRef]

97. Zhao, J.; Lam, K.P.; Ydstie, B.E.; Loftness, V. Occupant-oriented mixed-mode EnergyPlus predictive control simulation. Energy Build. 2016, 117, 362-371. [CrossRef]

98. Feng, X.; Yan, D.; Wang, C.; Sun, H. A preliminary research on the derivation of typical occupant behavior based on large-scale questionnaire surveys. Energy Build. 2016, 117, 332-340. [CrossRef]

99. Tahmasebi, F.; Mahdavi, A. An inquiry into the reliability of window operation models in building performance simulation. Build. Environ. 2016, 105, 343-357. [CrossRef]

100. Hong, T.; Taylor-Lange, S.C.; D'Oca, S.; Yan, D.; Corgnati, S.P. Advances in research and applications of energy-related occupant behavior in buildings. Energy Build. 2016, 116, 694-702. [CrossRef]

101. Yan, D.; O’Brien, W.; Hong, T.; Feng, X.; Burak Gunay, H.; Tahmasebi, F.; Mahdavi, A. Occupant behavior modeling for building performance simulation: Current state and future challenges. Energy Build. 2015, 107, 264-278. [CrossRef] 